\title{
RESPONSE OF GLADIOLUS CV. CARMEN TO COMPOST, BIOFERTILIZATION AND SOME VITAMIN TREATMENTS
}

\author{
M.A.H. Abdou ${ }^{*}$ and T.I.E. Ibrahim ${ }^{* *}$ \\ * Horticulture Dept., Fac. Agric., Minia Univ., Egypt. \\ ** Ministry of Agriculture, Egypt.
}

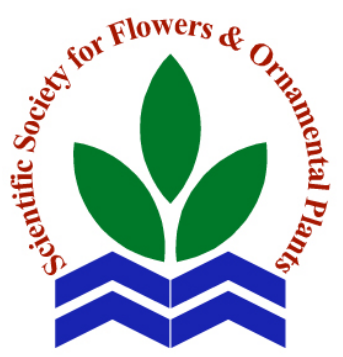

Scientific J. Flowers \& Ornamental Plants, 2(1):1-10 (2015).

Received:

$24 / 11 / 2014$

Revised by: Prof. Dr. E.S. Nofal, Kafr El-Sheikh Univ.

Prof. Dr. A.Z. Sarhan, Cairo Univ.
ABSTRACT: A field experiment was carried out during the two successive seasons of 2012/2013 and 2013/2014 to study the effect of compost and biofertilizers, as well as, some vitamins and their interaction on Gladiolus grandiflorus cv. Carmen plant.

Results showed that vegetative growth (leaf length, number of leaves/plant and dry weight of leaves/plant), flowering aspects (length of spike, number of florets/spike and lower floret diameter) and corms productivity (corm diameter, corm dry weight and number of cormels per plant) were gradually increased by increasing the level of compost fertilizer.

All biofertilizers and vitamins treatments significantly increased all vegetative growth characters, flowering parameters and corm and cormels productivity in comparison with the control. Effective microorganisms (E.M.) + active dry yeast (A.Y.) treatment seemed to be more effective than other treatments in this concern.

The use of high level of compost ( 21 ton/fed) in combination with combined biofertilizers noticeably improved the different vegetative growth characters, flowering parameters and corms productivity of gladiolus.

Key words: Gladiolus grandiflorus, cv. Carmen, compost, biofertilizers, vitamins, vegetative growth, flowering, corms productivity.

\section{INTRODUCTION}

Gladiolus grandiflorus, L. plants are considered one of the most important flowering bulbs grown in Egypt. Gladiolus belongs to Family Iridaceae and is propagated by corms. It has a decorative spike which carries numerous florets. There are fast expands in areas planted with gladiolus in Egypt in order to meet the increase demand for gladiolus flowers for local market and export.

Organic, biofertilizers and antioxidants (vitamins) are among the important agricultural treatments which have been proved to improve the vegetative growth and flowering aspects, as well as, corms productivity of gladiolus plants.

Many investigators revealed the importance of organic fertilization on the growth, flowering quality and corms productivity of gladiolus. Gangadharan and Gopinath (2000), Conte et al. (2001), Khan et al. (2002), Atta-Alla et al. (2003), Dongardive et al. (2007), Hassanein and ElSayed (2009a) and (2009b), Leonardo and Barbara (2011) and Chandar et al. (2012) reported that treated gladiolus plants with organic fertilization resulted in significant increase in plant height, number of leaves, leaf area, fresh and dry weights of whole plant, as well as, spike length, number of 
florets/spike and corms productivity in comparison with untreated plants.

Concerning the effect of biofertilizers, Kathiresan et al. (2002), Abdou et al. (2004), Badran et al. (2006), Taha and Hassan (2008a) and (2008b), Hassanein and ElSayed (2009a) and (2009b), Dalve et al. (2009) and Ahmed (2013) found that biofertilization treatments improved vegetative growth, flower characters and corms productivity of gladiolus.

Abdel Aziz et al. (2009), Alabdaly (2012) and Ahmed (2013) on gladiolus pointed out that application treatments of vitamins led to significant increases in vegetative growth traits and flowering productivity.

The aim of the present study was to investigate the effect of compost as organic fertilizer, biofertilizers and vitamin treatments on the vegetative growth, flowering and corms productivity of gladiolus cv. Carmen.

\section{MATERIALS AND METHODS}

A field experiment was carried out during the two successive seasons of $2012 / 2013$ and 2013/2014 at the Nursery of Ornamental plants, Fac. Agric. Minia Univ. to figure out the response of Gladiolus grandiflorus cv. Carmen to organic, biofertilizers and some vitamin treatments.

The corms of gladiolus were obtained from Holland by Basiouny nurseries, Cairo, Egypt. Average corm diameter was 3.0 and $3.3 \mathrm{~cm}$ and corm weight was 9.9 and $10.5 \mathrm{~g}$ for the first season and second one, respectively. Corms were planted on October $7^{\text {th }}$ for both seasons in $2 \times 2.2 \mathrm{~m}$ plots containing 3 ridges, $50 \mathrm{~cm}$ apart, corms were planted in hills, $20 \mathrm{~cm}$ apart (10 corms/ridge). Physical and chemical properties of the soil used are listed in Table (a). The split plot design with three replicates was followed in this experiment.

The four levels of compost fertilization treatments were considered as main plots and the eight biofertilizer and vitamin treatments
(Control, E.M., A.Y., vit. E, vit. B 1 , E.M. + A.Y., E.M. + vit. E and E.M. + vit. B ${ }_{1}$ ) were put in the sub-plots. The four levels of compost treatments were $0.0,7,14$ and 21 ton/fed. The compost was added before planting during the soil preparation. Compost analysis is shown in Table (b).

The sub-plot treatments were as follows:

1- Without any treatment (control).

2- Effective microorganisms (E.M.) at 50 $\mathrm{ml} / \mathrm{plant}$.

3- Active yeast (A.Y.) at $5 \mathrm{~g} / \mathrm{l}$.

4- Alpha-tocopherol (vit. E) at 30 ppm.

5- Thiamine (vit. $B_{1}$ ) at $50 \mathrm{ppm}$.

6- E.M. + A.Y.

7- E.M. + vit. E

8- E.M. + vit. B .

The plants were foliar sprayed three times, one month and two months after planting and after flower cut.

Effective microorganisms (E.M.) as a biofertilizer containing photosynthetic bacteria, lactic acid and yeasts and $1 \mathrm{ml}$ contained $10^{7}$ cells of bacteria. This biofertilizer was obtained from the Laboratory of Biofertilizers, Dept. of Genetics, Fac. Agric., Minia Univ.

The dry matter of active dry yeast (Saccharomyces cerevisiae), was $95 \%$ and live cells were $11.6 \times 10^{9} / \mathrm{g}$. The yeast suspension was prepared by dissolving dry yeast and sugar together $(1: 1 \mathrm{w} / \mathrm{w})$ in a warm water $\left(38{ }^{\circ} \mathrm{C}\right)$ and let it stand for two hours before spraying to enhance yeast activity (A.Y.) (Skoog and Miller, 1957). Chemical analysis of the dry yeast is presented in Table (c).

Thiamine (vit. $\mathrm{B}_{1}$ ) was obtained from ElGomhoria Company for chemicals, Egypt and $\alpha$-tocopherol (vit. E) was supplied by Sigma Chemical Company, USA. E.M. was applied three times to the soil around each plant. Each of alpha-tocopherol, thiamine and active yeast were applied by hand sprayer, 3 times on the plants till run off. All 
Table a. Physical and chemical properties of the experimental soil.

\begin{tabular}{|c|c|c|c|}
\hline Soil Character & \multicolumn{3}{|c|}{ Value } \\
\hline Sand \% & \multicolumn{3}{|c|}{28.00} \\
\hline Silt \% & \multicolumn{3}{|c|}{30.90} \\
\hline Clay \% & \multicolumn{3}{|c|}{41.10} \\
\hline Texture grade & \multicolumn{3}{|c|}{ Clayey loam } \\
\hline Organic matter \% & \multicolumn{3}{|c|}{1.65} \\
\hline $\mathrm{CaCO}_{3} \%$ & \multicolumn{3}{|c|}{2.08} \\
\hline E.C. (m mhos/cm) & \multicolumn{3}{|c|}{1.04} \\
\hline pH (1:2.5) & \multicolumn{3}{|c|}{7.82} \\
\hline Total N \% & \multicolumn{3}{|c|}{0.08} \\
\hline \multicolumn{4}{|c|}{$\begin{array}{l}\text { Table b. Chemical analysis of the compost } \\
\text { (average of the two seasons). }\end{array}$} \\
\hline Properties & Value & Properties & Value \\
\hline pH & 8.0 & Fe (ppm) & 1750 \\
\hline Humidity (\%) & 26 & Mn (ppm) & 125 \\
\hline Organic matter (\%) & 44 & $\mathrm{Cu}$ (ppm) & 200 \\
\hline $\mathbf{N}(\%)$ & 1.5 & Zn (ppm) & 60 \\
\hline P (\%) & 0.5 & $\mathrm{C} / \mathrm{N}$ ratio & 17.5 \\
\hline K (\%) & 1.0 & & \\
\hline
\end{tabular}

Table c. Chemical analysis of the used active dry yeast.

\begin{tabular}{lc}
\hline Properties & Value \\
\hline Proteins (\%) & 34.87 \\
Ash (\%) & 7.55 \\
Glycogen (\%) & 6.54 \\
Fats (\%) & 2.09 \\
Cellulose (\%) & 4.92 \\
\hline
\end{tabular}

agricultural practices were performed as usual, in the region. The following data were recorded:

1- Vegetative growth characters just before flowering: leaf length $(\mathrm{cm})$, number of leaves/plant and dry weight of leaves (g/plant).

2- Flowering characters: spike length $(\mathrm{cm})$, number of florets/spike and lower floret diameter $(\mathrm{cm})$.

3- Under ground parts characters at harvesting after foliage had drying (under ground parts were lifted two months after cut spikes): corm diameter $(\mathrm{cm})$, corm dry weight $(\mathrm{g})$ and number of new cormels/plant.

\begin{tabular}{|c|c|}
\hline Soil Character & Value \\
\hline Available P \% & 15.15 \\
\hline Exch. $K^{+}(\mathrm{mg} / 100 \mathrm{~g})$ & 2.16 \\
\hline Exch. $\mathrm{Ca}^{++}(\mathrm{mg} / 100 \mathrm{~g})$ & 31.64 \\
\hline Exch. $\mathrm{Na}^{+}(\mathrm{mg} / 100 \mathrm{~g})$ & 2.43 \\
\hline \multirow{4}{*}{$\begin{array}{l}\text { DTPA } \\
\text { Ext.ppm }\end{array}$} & 8.54 \\
\hline & 2.06 \\
\hline & 2.75 \\
\hline & 8.26 \\
\hline
\end{tabular}

All of the obtained data were subjected to the statistical analysis of variance using MSTAT-C (1986). L.S.D. test at 0.05 was used to compare the average means of treatments.

\section{RESULTS AND DISCUSSION}

\section{1- Vegetative growth characters:}

Data presented in Table (1) show that leaf length, number of leaves/plant and leaves dry weight/plant of gladiolus were significantly increased in both seasons due to the use of compost at 7,14 and 21 ton/fed in comparison with those of untreated plants. The highest values were obtained from compost at high level (21 ton/fed). The increase of vegetative growth resulting from using compost as organic fertilization treatments might be due to the fact that organic matter is considered as an important factor for improving physical, chemical and biological properties of the soil and consequently, increased plant growth (Maynard, 1991). Similar results were obtained by Gangadharan and Gopinath (2000), Conte et al. (2001), Atta-Alla et al. (2003), Hassanein and El-Sayed (2009a), Chandar et al. (2012) and Ahmed (2013) on gladiolus.

Data presented in Table (1) indicated that, leaf length, number of leaves/plant and leaves dry weight were significantly increased, in both seasons, due to the use of the seven treatments of biofertilizers (E.M. and/or A.Y.), vitamins (vit. E and vit. $B_{1}$ ) and E.M. and/or vitamins (vit. E or vit. $\mathrm{B}_{1}$ ) in comparison with untreated control. The combined treatment of E.M. + A.Y. seemed 
Table 1. Effect of compost, bio-fertilizer and some vitamin treatments on leaf length (cm), number of leaves/plant and leaves dry weight/plant (g) of Gladiolus grandiflorus cv. Carmen, during 2012/2013 and 2013/2014 seasons.

\begin{tabular}{|c|c|c|c|c|c|c|c|c|c|c|}
\hline \multirow{3}{*}{$\begin{array}{c}\text { Bio-fertilizer and } \\
\text { some vitamin } \\
\text { treatments }\end{array}$} & \multicolumn{10}{|c|}{ Compost levels (ton/fed) (A) } \\
\hline & \multicolumn{5}{|c|}{$1^{\text {st }}$ season } & \multicolumn{5}{|c|}{$2^{\text {nd }}$ season } \\
\hline & $\mathbf{0}$ & 7 & 14 & 21 & Mean (B) & $\mathbf{0}$ & 7 & 14 & 21 & $\begin{array}{c}\text { Mean } \\
\text { (B) }\end{array}$ \\
\hline \multicolumn{11}{|c|}{ Leaf length (cm) } \\
\hline Control & 26.7 & 32.9 & 37.2 & 39.5 & 34.10 & 28.2 & 34.6 & 39.1 & 41.7 & 35.88 \\
\hline E.M. & 29.9 & 36.9 & 42.0 & 45.2 & 38.51 & 31.6 & 39.0 & 44.4 & 47.9 & 40.73 \\
\hline A.Y. & 29.0 & 35.7 & 40.6 & 43.6 & 37.21 & 30.8 & 37.9 & 43.1 & 46.5 & 39.61 \\
\hline Vit. E & 27.6 & 34.1 & 38.6 & 41.1 & 35.34 & 29.4 & 36.1 & 40.9 & 43.9 & 37.57 \\
\hline Vit. $B_{1}$ & 27.5 & 34.0 & 38.5 & 41.0 & 35.24 & 29.3 & 36.0 & 40.8 & 43.7 & 37.43 \\
\hline E.M. + A.Y. & 31.1 & 38.5 & 43.9 & 47.3 & 40.19 & 32.8 & 40.5 & 46.2 & 50.1 & 42.41 \\
\hline E.M. + Vit. E & 28.6 & 35.3 & 40.1 & 42.9 & 36.72 & 30.3 & 37.2 & 42.2 & 45.4 & 38.79 \\
\hline E.M. + Vit. B 1 & 28.4 & 35.0 & 39.7 & 42.4 & 36.36 & 30.1 & 36.9 & 41.9 & 45.1 & 38.51 \\
\hline Mean (A) & 28.60 & 35.29 & 40.07 & 42.88 & & 30.30 & 37.28 & 42.33 & 45.53 & \\
\hline
\end{tabular}

L.S.D. at $5 \% \quad$ A: $2.35 \quad$ B: $0.86 \quad$ AB: $1.72 \quad$ A: $2.81 \quad$ B: $1.10 \quad$ AB: 2.20

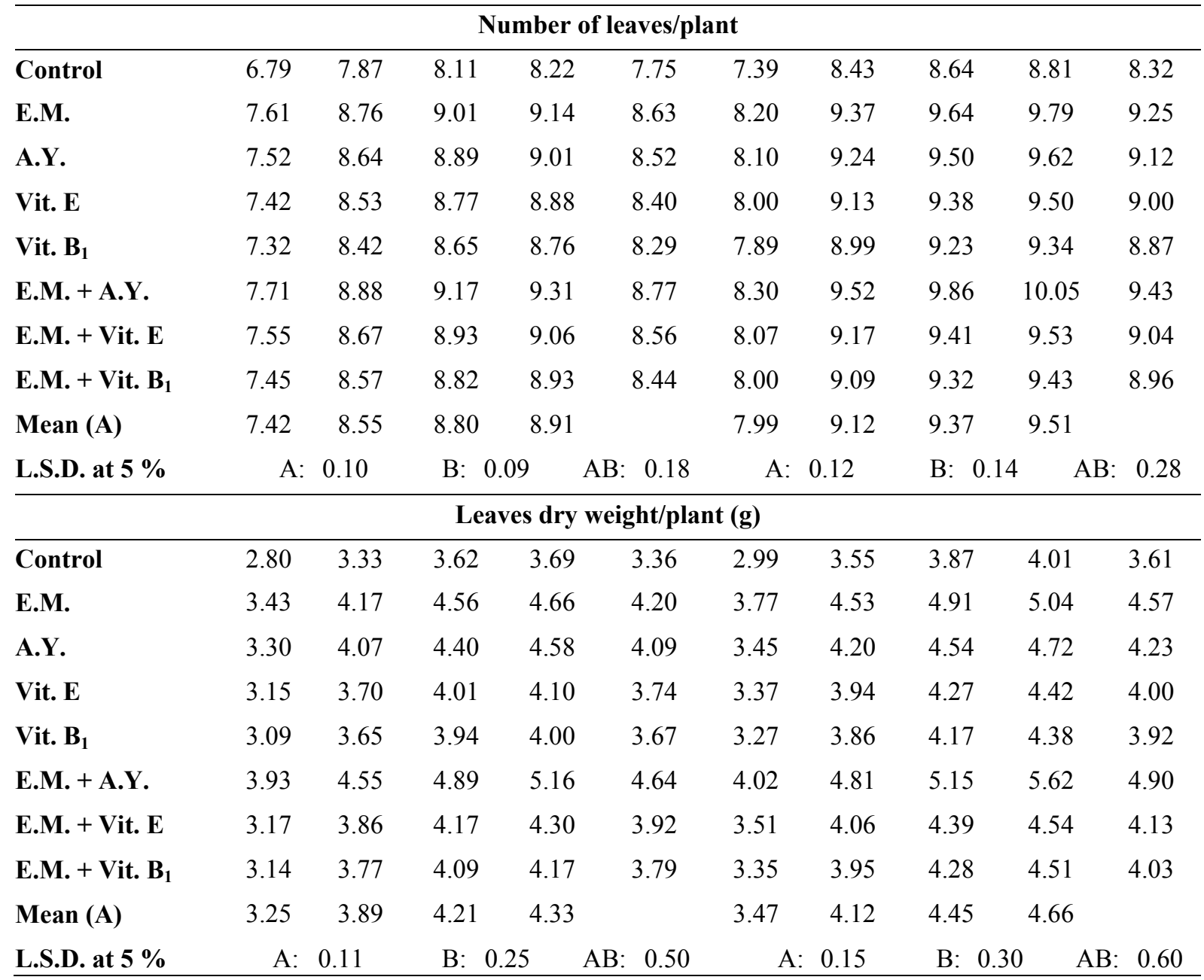

E.M. : Effective microorganisms A.Y.: Active yeast 
to be more effective than either biofertilizer alone or vitamins. In conformity with these results were those detected by Kathiresan et al. (2002), Abdou et al. (2004), Taha and Hassan (2008a), Hassanein and El-Sayed (2009a) and Ahmed (2013) on gladiolus.

The role of E.M. and active yeast as biofertilizers in promoting vegetative growth might be attributed to the increase in nutrient uptake and to their contents or synthesis of plant hormones. Consequently, increasing the formation of metabolites which encourage the vegetative growth and enhance meristematic activity of cells and tissues to improve leaf production (Sperenat, 1997; Hassan, 1997; Gabra, 2004 and Ismail, 2008).

The interaction between the two factors was significant in the two seasons for leaf length, leaf number and leaves dry weight. The maximum leaf length, number of leaves/plant and leaves dry weight/plant, were obtained due to supplying the soil with 21 ton/fed compost in combination with E.M. + A.Y. followed by the high level of compost (21 ton/fed) with E.M.

\section{2- Flowering parameters:}

Data presented in Table (2) show that all compost level treatments caused significant increase in length of spike, number of florets/spike and lower floret diameter, in the two seasons, in comparison with that of untreated plants. The flowering parameters were gradually increased due to the increase in the levels of compost fertilizer. However, non-significant differences were detected between the high and medium levels for length of spike in both seasons. These results are in close agreement with those obtained by Pimpini and Zanin (2002), Atta-Alla et al. (2003), Dongardive et al. (2007), Hassanein and El-Sayed (2009a) and Ahmed (2013) on gladiolus.

A possible explanation to the positive effect of compost fertilizer treatments might be attributed to its stimulative effect on the different vegetative growth traits (Table, 1).
Better vegetative growth is directly reflected on various flowering aspects.

Regarding biofertilization (E.M. and/or A.Y.), vitamins (vit. E and vit. $B_{1}$ ) and their combination data presented in Table (2) revealed that all seven used treatments significantly increased length of spike, number of florets/spike and lower florets diameter compared with untreated plants. The highest values were obtained due to either the treatments of E.M. + A.Y. or E.M. for spike length and E.M. + A.Y. or used each of biofertilizers alone for number of florets/spike and E.M. + A.Y. followed by A.Y. for lower floret diameter. These findings were similar to those obtained by Abdou et al. (2004), Taha and Hassan (2008a) and Hassanein and El-Sayed (2009a) on gladiolus and Romuald and Tomasz (2010) on rose and gerbera.

These results might be attributed to the direct and/or indirect role of substances (nutrients, amino acids, vitamins, auxin, cytokinin and gibberellins) (Nagodawithana, 1991 and Sperenat, 1997), all those have better effects on the plant growth, consequently improving enzymatic system that reflected on the flowering of gladiolus.

The interaction between factor (A) and factor (B) was significant in the two seasons for the three studied flowering characters. The best overall results were obtained due to the use of compost at the high level in combination with E.M. + A.Y. followed by the high level of compost with either biofertilizer.

\section{3- Corm and cormels productivity:}

Data presented in Table (3) indicated that corm diameter, corm dry weight and number of cormels/plant were significantly increased with increasing compost fertilizer levels, during the two growing seasons, in comparison with control. The high level of compost (21 ton/fed) resulted in the highest values for all corm and cormels production traits. Similar results were revealed on gladiolus by Liu et al. (1998), Gangadharan and Gopinath (2000), Conte et al. (2001), 
Table 2. Effect of compost, bio-fertilizer and some vitamin treatments on spike length (cm), number of florets/spike and lower floret diameter $(\mathrm{cm})$ of Gladiolus grandiflorus cv. Carmen, during 2012/2013 and 2013/2014 seasons.

\begin{tabular}{|c|c|c|c|c|c|c|c|c|c|c|}
\hline \multirow{3}{*}{$\begin{array}{l}\text { Bio-fertilizer and } \\
\text { some vitamin } \\
\text { treatments }\end{array}$} & \multicolumn{10}{|c|}{ Compost levels (ton/fed) (A) } \\
\hline & \multicolumn{5}{|c|}{$1^{\text {st }}$ season } & \multicolumn{5}{|c|}{$2^{\text {nd }}$ season } \\
\hline & $\mathbf{0}$ & 7 & 14 & 21 & $\begin{array}{c}\text { Mean } \\
\text { (B) }\end{array}$ & $\mathbf{0}$ & 7 & 14 & 21 & $\begin{array}{c}\text { Mean } \\
\text { (B) }\end{array}$ \\
\hline \multicolumn{11}{|c|}{ Spike length (cm) } \\
\hline Control & 70.3 & 78.4 & 81.4 & 83.2 & 78.3 & 70.4 & 78.6 & 81.7 & 83.6 & 78.6 \\
\hline E.M. & 85.6 & 88.9 & 91.7 & 92.7 & 89.8 & 85.8 & 89.1 & 91.8 & 93.1 & 90.0 \\
\hline A.Y. & 84.5 & 88.1 & 90.7 & 91.5 & 88.7 & 85.0 & 87.9 & 91.0 & 92.3 & 89.0 \\
\hline Vit. E & 80.2 & 85.2 & 88.3 & 88.2 & 85.5 & 82.0 & 86.3 & 88.3 & 89.8 & 86.6 \\
\hline Vit. $B_{1}$ & 78.6 & 83.6 & 85.8 & 86.7 & 83.7 & 80.6 & 84.8 & 86.8 & 88.2 & 85.1 \\
\hline E.M. + A.Y. & 86.5 & 90.3 & 93.6 & 94.8 & 91.3 & 86.8 & 90.7 & 94.2 & 95.1 & 91.7 \\
\hline E.M. + Vit. E & 82.3 & 86.8 & 89.4 & 90.1 & 87.1 & 84.0 & 87.5 & 89.9 & 90.4 & 87.9 \\
\hline E.M. + Vit. B 1 & 80.7 & 86.2 & 88.8 & 89.4 & 86.3 & 82.6 & 87.0 & 89.3 & 90.8 & 87.4 \\
\hline Mean (A) & 81.1 & 86.0 & 88.7 & 89.6 & & 82.1 & 86.5 & 89.1 & 90.4 & \\
\hline
\end{tabular}

$\begin{array}{lllllllll}\text { L.S.D. at } 5 \% & \text { A: } 1.2 & \text { B: } 1.5 & \text { AB: } 3.0 & \text { A: } 1.5 & \text { B: } 1.7 & \text { AB: } 3.4\end{array}$

Number of florets/spike

\begin{tabular}{|c|c|c|c|c|c|c|c|c|c|c|}
\hline Control & 7.82 & 8.95 & 9.61 & 9.74 & 9.03 & 8.18 & 9.30 & 9.47 & 9.85 & 9.20 \\
\hline E.M. & 8.94 & 10.46 & 11.60 & 12.22 & 10.81 & 9.27 & 10.98 & 11.63 & 12.50 & 11.11 \\
\hline A.Y. & 8.95 & 10.35 & 11.51 & 12.02 & 10.71 & 9.26 & 10.91 & 11.51 & 12.39 & 11.02 \\
\hline Vit. E & 8.63 & 9.88 & 10.64 & 10.89 & 10.01 & 9.01 & 10.37 & 10.58 & 11.17 & 10.28 \\
\hline Vit. $B_{1}$ & 8.53 & 9.67 & 10.32 & 10.46 & 9.75 & 8.90 & 10.08 & 10.17 & 10.67 & 9.96 \\
\hline E.M. + A.Y. & 9.06 & 10.50 & 11.70 & 12.39 & 10.92 & 9.37 & 11.07 & 11.86 & 12.61 & 11.23 \\
\hline E.M. + Vit. E & 8.87 & 10.18 & 11.29 & 11.62 & 10.49 & 9.17 & 10.80 & 11.30 & 12.00 & 10.82 \\
\hline E.M. + Vit. B 1 & 8.74 & 10.09 & 10.96 & 11.30 & 10.27 & 9.08 & 10.58 & 11.00 & 11.67 & 10.58 \\
\hline Mean (A) & 8.70 & 10.01 & 10.96 & 11.33 & & 9.03 & 10.51 & 10.94 & 11.60 & \\
\hline L.S.D. at $5 \%$ & A: & 0.35 & \multicolumn{2}{|c|}{ B: 0.21} & B: 0.42 & A: & 0.55 & B: 0.21 & $\mathrm{AB}:$ & 0.42 \\
\hline \multicolumn{11}{|c|}{ Lower floret diameter (cm) } \\
\hline Control & 6.78 & 7.56 & 7.60 & 7.83 & 7.45 & 7.14 & 7.29 & 7.55 & 7.97 & 7.49 \\
\hline E.M. & 8.11 & 8.19 & 8.24 & 8.58 & 8.28 & 8.04 & 8.25 & 8.55 & 8.88 & 8.44 \\
\hline A.Y. & 8.18 & 8.42 & 8.46 & 8.86 & 8.48 & 8.20 & 8.42 & 8.78 & 9.13 & 8.63 \\
\hline Vit. E & 7.56 & 7.68 & 7.77 & 7.91 & 7.73 & 7.51 & 7.73 & 7.97 & 8.30 & 7.87 \\
\hline Vit. $B_{1}$ & 7.56 & 7.46 & 7.65 & 7.81 & 7.62 & 7.53 & 7.57 & 7.91 & 8.21 & 7.80 \\
\hline E.M. + A.Y. & 8.21 & 8.65 & 8.58 & 9.06 & 8.63 & 8.19 & 8.64 & 9.06 & 9.35 & 8.81 \\
\hline E.M. + Vit. E & 7.92 & 8.01 & 8.11 & 8.36 & 8.10 & 7.82 & 8.04 & 8.34 & 8.65 & 8.21 \\
\hline E.M. + Vit. $B_{1}$ & 7.84 & 7.86 & 7.97 & 8.14 & 7.96 & 7.73 & 7.92 & 8.21 & 8.53 & 8.10 \\
\hline Mean (A) & 7.77 & 7.98 & 8.05 & 8.32 & & 7.76 & 7.99 & 8.29 & 8.63 & \\
\hline L.S.D. at $5 \%$ & A: & 0.21 & B: 0.1 & & B: 0.32 & A: & 0.24 & B: 0.18 & AB: & 0.36 \\
\hline
\end{tabular}

E.M.: Effective microorganisms A.Y.: Active yeast 
Table 3. Effect of compost, bio-fertilizer and some vitamin treatments on corm diameter (cm), corm dry weight (g) and number of cormels/plant of Gladiolus grandiflorus cv. Carmen, during 2012/2013 and 2013/2014 seasons.

\begin{tabular}{|c|c|c|c|c|c|c|c|c|c|c|}
\hline \multirow{3}{*}{$\begin{array}{l}\text { Bio-fertilizer and } \\
\text { some vitamin } \\
\text { treatments }\end{array}$} & \multicolumn{10}{|c|}{ Compost levels (ton/fed) (A) } \\
\hline & \multicolumn{5}{|c|}{$1^{\text {st }}$ season } & \multicolumn{5}{|c|}{$2^{\text {nd }}$ season } \\
\hline & $\mathbf{0}$ & 7 & 14 & 21 & $\begin{array}{c}\text { Mean } \\
\text { (B) }\end{array}$ & $\mathbf{0}$ & 7 & 14 & 21 & $\begin{array}{c}\text { Mean } \\
\text { (B) }\end{array}$ \\
\hline \multicolumn{11}{|c|}{ Corm diameter $(\mathrm{cm})$} \\
\hline Control & 3.31 & 3.86 & 4.15 & 4.50 & 3.96 & 3.92 & 4.05 & 4.24 & 4.45 & 4.17 \\
\hline E.M. & 4.29 & 4.95 & 5.17 & 5.49 & 4.98 & 4.33 & 5.05 & 5.18 & 5.69 & 5.07 \\
\hline A.Y. & 4.12 & 4.81 & 5.15 & 5.27 & 4.84 & 4.22 & 4.90 & 4.96 & 5.57 & 4.93 \\
\hline Vit. E & 3.53 & 4.21 & 4.42 & 4.54 & 4.17 & 3.92 & 4.51 & 4.71 & 5.05 & 4.55 \\
\hline Vit. $B_{1}$ & 3.54 & 4.17 & 4.32 & 4.41 & 4.11 & 3.97 & 4.41 & 4.61 & 4.91 & 4.48 \\
\hline E.M. + A.Y. & 4.34 & 5.05 & 5.48 & 5.73 & 5.15 & 4.44 & 5.15 & 5.29 & 5.95 & 5.43 \\
\hline E.M. + Vit. E & 3.69 & 4.39 & 4.68 & 4.75 & 4.38 & 4.11 & 4.70 & 4.95 & 5.27 & 4.76 \\
\hline E.M. + Vit. B 1 & 3.55 & 4.24 & 4.54 & 4.63 & 4.24 & 3.97 & 4.56 & 4.80 & 5.12 & 4.62 \\
\hline Mean (A) & 3.79 & 4.46 & 4.74 & 4.92 & & 4.11 & 4.66 & 4.84 & 5.36 & \\
\hline L.S.D. at $5 \%$ & A: & 0.15 & B: 0.1 & & AB: 0.22 & A: & 0.16 & B: 0.12 & AB: & $: 0.24$ \\
\hline \multicolumn{11}{|c|}{ Corm dry weight (g) } \\
\hline Control & 21.96 & 25.17 & 27.91 & 30.36 & 26.35 & 27.35 & 28.92 & 30.15 & 31.88 & 29.58 \\
\hline E.M. & 29.62 & 34.31 & 36.14 & 38.62 & 34.68 & 30.36 & 35.68 & 37.08 & 40.77 & 35.98 \\
\hline A.Y. & 27.57 & 32.43 & 35.08 & 36.17 & 32.82 & 28.23 & 33.08 & 35.29 & 39.93 & 34.13 \\
\hline Vit. E & 22.99 & 28.29 & 34.49 & 31.24 & 29.26 & 27.41 & 31.84 & 33.61 & 35.08 & 31.98 \\
\hline Vit. $B_{1}$ & 23.58 & 28.09 & 29.48 & 30.36 & 27.88 & 27.42 & 30.95 & 32.72 & 34.92 & 31.57 \\
\hline E.M. + A.Y. & 29.30 & 34.67 & 37.94 & 40.35 & 35.57 & 32.06 & 37.43 & 38.88 & 44.08 & 38.11 \\
\hline E.M. + Vit. E & 24.67 & 29.64 & 31.92 & 32.99 & 29.81 & 28.67 & 33.02 & 35.08 & 37.73 & 33.63 \\
\hline E.M. + Vit. B 1 & 23.68 & 28.89 & 30.94 & 31.82 & 28.83 & 27.71 & 32.14 & 34.19 & 36.55 & 32.65 \\
\hline Mean (A) & 25.30 & 30.20 & 32.99 & 34.00 & & 28.69 & 32.88 & 34.63 & 37.62 & \\
\hline L.S.D. at $5 \%$ & A: & 0.93 & B: 0.8 & & AB: 1.70 & A: & 1.11 & B: 1.64 & AB: & 3.28 \\
\hline \multicolumn{11}{|c|}{ Number of cormels/plant } \\
\hline Control & 22.7 & 28.8 & 31.8 & 33.0 & 29.1 & 26.4 & 33.3 & 36.1 & 38.5 & 33.5 \\
\hline E.M. & 28.4 & 36.3 & 38.0 & 38.7 & 35.4 & 34.6 & 40.5 & 43.6 & 45.9 & 41.2 \\
\hline A.Y. & 27.5 & 36.0 & 37.2 & 38.3 & 34.7 & 33.7 & 39.7 & 42.0 & 44.5 & 40.0 \\
\hline Vit. E & 26.3 & 33.8 & 34.5 & 34.8 & 32.4 & 32.3 & 36.9 & 37.5 & 40.5 & 36.8 \\
\hline Vit. $B_{1}$ & 25.4 & 33.3 & 33.1 & 33.4 & 31.3 & 31.4 & 36.4 & 36.7 & 39.5 & 36.0 \\
\hline E.M. + A.Y. & 31.8 & 39.1 & 40.2 & 43.3 & 38.6 & 36.9 & 42.8 & 46.7 & 49.4 & 43.9 \\
\hline E.M. + Vit. E & 27.1 & 35.4 & 36.5 & 37.4 & 34.0 & 33.3 & 38.8 & 40.6 & 42.8 & 38.9 \\
\hline E.M. + Vit. B 1 & 26.5 & 34.4 & 35.6 & 36.5 & 33.2 & 32.4 & 37.5 & 39.5 & 42.2 & 37.9 \\
\hline Mean (A) & 27.0 & 34.6 & 35.9 & 37.0 & & 32.6 & 38.3 & 40.3 & 42.9 & \\
\hline L.S.D. at $5 \%$ & A: & 1.1 & $\mathrm{~B}:$ & & AB: & A: & 1.3 & B: $\quad 1.7$ & AB: & 2.4 \\
\hline
\end{tabular}

E.M.: Effective microorganisms A.Y.: Active yeast 
Zaghloul and Atta-Alla (2001), Atta-Alla et al. (2003), Taha and Hassan (2008b), Hassanein and El-Sayed (2009b) and Ahmed (2013).

The increase in the corm productivity was attributed to the positive effect of organic fertilizers on improving the vegetative growth, as well as, stimulating chlorophyll synthesis (Hassanein and ElSayed, 2009b) which reflect on increasing the underground organs of gladiolus.

In relation to the sub-plot treatments, the seven tested ones significantly surpassed, the control treatment in both seasons in producing wider corms, higher number of new cormels/plant and heavier dry weights of corms. Biofertilizers were more effective than vitamin treatments. Also, the use of the two biofertilizers together was more effective than each one alone. Therefore, the treatment of E.M. + A.Y. followed by E.M. treatment resulted in the highest value in this concern. Similar observations were pointed out on gladiolus by Kathiresan et al. (2002), Abdou et al. (2004), Taha and Hassan (2008b) and Hassanein and El-Sayed (2009b).

The stimulatory effect of the treatments of biofertilizers on corms productivity may be due to the mode of action of biofertilizers on the soil or plant, plant hormone, enzymes and vitamins which came from addition of biofertilizers, and gave better growth consequently increased all corm productivity parameters. Moreover, vitamin treatments were found to have stimulatory effects on growth, flowering and bulb production on gladiolus, (Abdel Aziz et al., 2009; Alabdaly, 2012 and Ahmed, 2013).

The interaction between the main and sub plot treatments was significant, in both seasons, in regard to corm diameter, corm dry weight and cormels number/plant. The highest values were obtained for all corm productivity parameters when gladiolus plants received compost at 21 ton/fed in combination with E.M. + A.Y.

\section{REFERENCES}

Abdel Aziz, G.N.; Taha, L. and Ibrahim, S.M.M. (2009). Some studies on the effect of putrescine, ascorbic acid and thiamine on growth, flowering and some chemical constituents of gladiolus at Nubaria. Ozean J. of Applied Sci., 2(2):169-179.

Abdou, M.A.H.; Attia, F.; Aly, M.K. and Sayed, I.H. (2004). Response of gladiolus plants to some bio and chemical fertilization treatments. 1- Vegetative growth and flowering; Proc. Fifth Arabian Hort. Conf., Ismailia, Egypt, 2428 March, vol. (1):50-62.

Ahmed, A.S.A. (2013). Effect of Compost, Biofertilization and Some Vitamins on Gladiolus grandiflorus. M.Sc. Thesis, Fac. Agric. Minia Univ.

Alabdaly, H.M. (2012). Effect of putrescine and thiamine application treatments on vegetative growth and flowering of Gladiolus grandiflorus, L. plants. Anbar J. of Agric. Sci., 10(1):97-106.

Atta-Alla, H.K.; Zaghloul, M.A. and Hashish, K.H. (2003). Effect of organic manure and NPK fertilizers on vegetative growth, flowering and chemical composition of some Gladiolus cultivars. Annals Agric. Sci., Moshtohor, 41(2):680-691.

Badran, F.S.; Mohamed, M.A.; Meseha, A. and Hassan, Z.B. (2006). Effect of some biofertilizer sources on Gladiolus grandiflorus plants. Proc. $3^{\text {rd }}$ Egypt \& Syr. Conf. for Agric. \& food, El-Minia : Nov. 6-9, 2006, 3(1):119-129.

Chandar, I.; Rawat, I.; Lakhawat, S.S. and Yadav, K.K. (2012). Effect of organic manures and biofertilizers on the yield parameters of Gladiolus cv. White Prosperity. Ecol., Environ. and Conservation Paper, 18(1):91-94.

Conte, C.A.M.; Ruppenthal, V.; Zigiotto, D.C.; Bianchini, M.I.F. and Baches, C. (2001). Organic fertilization for the culture of the gladiolus. Scientia Agraria 
Paranaensis, J.; 1:33-41 (C.F. CAB Abst., ENAL).

Dalve, P.D.; Mane, S.V. and Ranadive, S.N. (2009). Effect of biofertilizers with reduced doses of nitrogen on corm quality of gladiolus. J. of Maharashtra Agric. Univ., 34(1):122-123.

Dongardive, S.B.; Golliwar, V.J. and Bhongle, S.A. (2007). Effect of organic manure and biofertilizers on growth and flowering in Gladiolus cv. White Prosperity. Plant Archives, 7(2):657-658.

Gabra, G.W.R. (2004). Physiological Studies on Some Ornamental Plants. M.Sc. Thesis, Fac. Agric., Kafr El-Sheikh, Tanta Univ.

Gangadharan, G.D. and Gopinath, G. (2000). Effect of organic and inorganic fertilizers on growth, flowering and quality of Gladiolus cv. White Prosperity. Karnataka J. Agric. Sci., 13(2):401-405(C.F. WWW.Bids.Ac.UK).

Hassanein, Magda M. and El-Sayed, Soheir G. (2009b). Effect of some organic and bio-fertilization treatments on gladiolus plants: 2-Corm production and chemical constituents. J. Agric. Sci. Mansoura Univ., 34(6):6255-6268.

Hassanein, Magda M. and El-Sayed, Soheir G. (2009a). Effect of some organic and bio-fertilization treatments on gladiolus plants: 1-Vegetative growth and flowering. J. Agric. Sci. Mansoura Univ., 34(6):6237-6254.

Hassan, M.E. (1997). Plant GrowthPromoting Rhizobacteria: An overview for Egypt Proceeding of the Training Course on Bio-Organic Farming System for Sustainable Agriculture. Cairo, Egypt.

Ismail, S.I.I. (2008). Anatomical and Physiological Studies on Nigella sativa, L. Plant. Ph.D. Thesis, Fac. Agric., Mansoura Univ., Egypt.

Kathiresan, C.; Venkatesha, J.; Misra, R.L. and Sanyat, M. (2002). Effect of biofertilizers with levels of $\mathrm{N}$ and $\mathrm{P}$ on
Gladiolus. Proc. National Symposium on Indian Floriculture in the new Millennium, Lai-Bagh, Bangalor, 25-27 February 2002. p: $120-123$ (C.F. www.bids.ac.uk).

Khan, S.; Khan, A.; Iqbal, A. and Rahman, M. (2002). Effect of different media on growth and quality of gladiolus (Gladiolus hortulanus cv. Jacksonville Gold). Asian J. Plant Sci., 1(6):670-671.

Leonardo, M. and Barbara, D.L. (2011). Organic and mineral soil fertilization in gladiolus. Compost Sci. and Utilization, 19(3):178-179.

Liu, W.C.; Wu, G.D.; Yao, T.P.; Chen, F.H. and Chen, W.H. (1998). Effect of soil factors and management practices on soil fertility and Gladiolus growth in a slate alluvial soil. Taiwan Sugat., 45(3):20-25. (C.F. CAB. Abst., ENAL).

Maynard, A.A. (1991). Intensive vegetative production using composted animal manures. The Connecticut Agricultural Experiment Station. New Haven, Bulletin, 894.

MSTAT-C (1986). A Microcomputer Program for the Design Management and Analysis of Agronomic Research Experiments (Version 4.0), Michigan State Univ., U.S.A.

Nagodawithana, W.T. (1991). Yeast Technology. Universal Foods Corporation Milwaukee, Wisconsin Published by Van Nostrand Reinhold, New York., 273 pp.

Pimpini, F. and Zanin, G. (2002). Gladiolus, Effect of soil type and fertilizer. Culture. Protette. 31(9):107-114. (C.F. www.beds.ac.uk).

Romuald, G. and Tomasz, K. (2010). Effect of effective microorganisms (E.M.) on nutrient contents in substrate and development and yielding of Rose (Rosa $\times$ hybrida) and Gerbera (Gerbera jamesonii). Ecol. Chem. and Engineering, 17(4):505-513. 


\section{M.A.H. Abdou and T.I.E. Ibrahim}

Skoog, F. and Millar, C. (1957). Biological Action of Growth Substances. Cambridge Univ. Press Camb. 1957-2000.

Sperenat, M. (1997). Nitrogen Fixing Organisms, P.S. Chapman and Hall. London.

Taha, R.A. and Hassan, A.H. (2008a). Response of gladiolus plants to mineral biofertilization and biofertilization treatments. 1- Vegetative growth and flowering. Alex. J. Agric. Res., 53:79-86.

Taha, R.A. and Hassan, A.H. (2008b). Response of gladiolus plants to mineral biofertilization and biofertilization treatments. 2- Corm production and chemical constituents. Alex. J. Agric. Res., 53:87-95.

Zaghloul, M.A.R. and Atta-Alla, H.K. (2001). Effect of irrigation, sewage sludge and cement dust on the vegetative growth, flowering and chemical composition of Gladiolus grown in sandy soil. Annals. Agric. Sci., Moshtohor, 39(1):565-583.

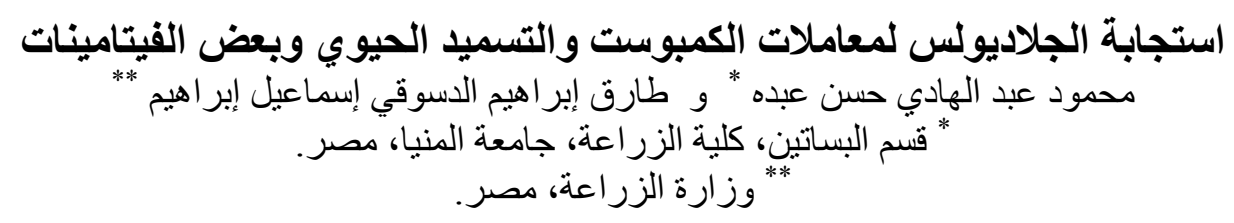

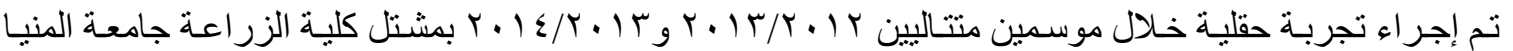

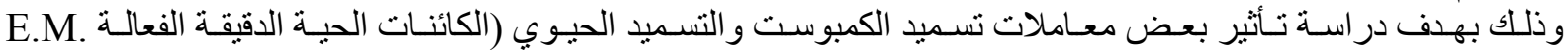

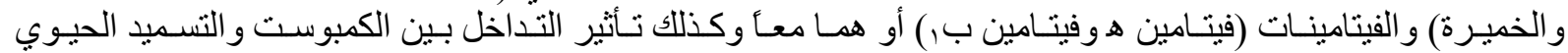

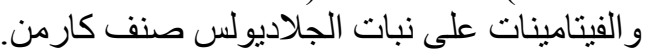

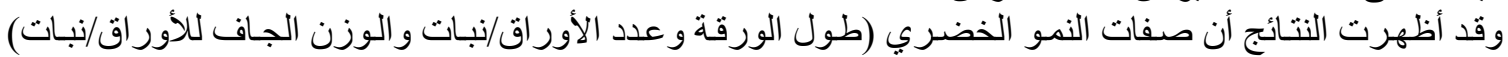

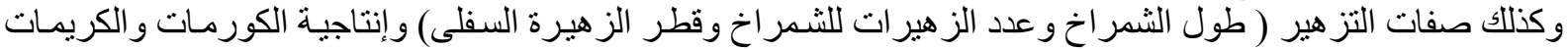

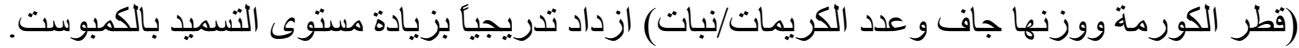

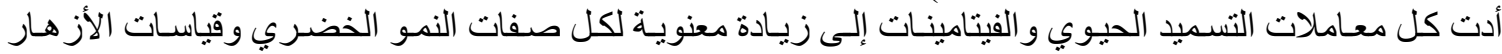

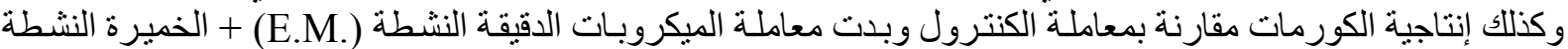

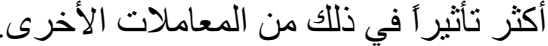

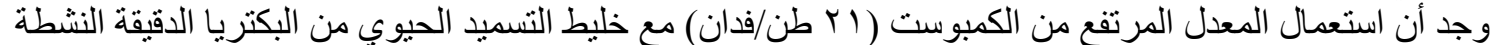

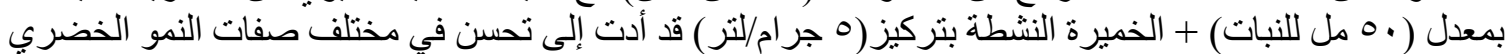
و الزهري و إنتاجية الكورمات لنباتات الجلاديولس لنئس صنف كارمن. 